\title{
A Critical Analysis on Social Security Measures For the Protection Of Workers in India
}

\section{${ }^{1}$ AUTHOR:Mrs.J.GAYATHRI ${ }^{2}$ CO-AUTHOR: Prof. Dr. DILSHAD SHAIK}

\begin{abstract}
Social security is the protection which society provides for its members through a series of public measures against economic and social distress that otherwise would be caused by the substantial stoppage of earnings. It also refers to the action programs undertaken by the government to promote the welfare of the people. The current study based on the empirical research. It is consisting of the scientific frame of research. It began with the finding of research problem based on the review of literature. The major contribution of the study is to collect the legal facts of particular area and to test the hypothesis of a cause effect relationship between variables. Convenience sampling method is used . Questionnaire is used as the primary data collection and the articles, journals, reports, newsletters are considered as the secondary sources. The analysis is carried out for demographic statistics and hypothesis testing chi square and cross tabulation is used.
\end{abstract}

\section{Key words}

Social Security, Contingent Poverty, Social Insurance, Legislation and Employers, India and Labour.

\section{Introduction}

Social security is a concept which overtime has gained importance in the industrialised countries. Broadly it can be defined as the measures providing protection to the working class against contingencies like retirement, resignation, retrenchment, maternity, old age, unemployment, death, disablement and other similar conditions (Bhattacharya, 1970). The Indian constitution levies responsibility on the state to provide social security measures to the citizens of our country. Social security systems also promote gender equality through adoption of various to ensure that women enjoy equal opportunities in the labour market (Sinha, 1980). Social security is an investment in building a nation that is just and humane

\footnotetext{
${ }^{1}$ Mrs. J. GAYATHRI MA., ML., Research Scholar, Vels Institute of Science, Technology and Advanced Studies, Chennai, India,gayathrijeni18@gmail.com.

${ }^{2}$ Prof. Dr. DILSHAD SHAIK, Research Supervisor, Vels Institute of Science, Technology and Advanced Studies, Chennai, India, dshaik786@gmail.com.
} 
resources. Social security is an investment in human resources which can provide overall security for a person within the family, workplaces and society. Social security includes measures designed to ensure that everyone has an adequate standard of living, including basic needs such as nutrition, housing, education, healthcare, clean water and sanitation and to live a life with dignity. This was found to be very insufficient, and it absolutely was soon accomplished that the chance of the people, particularly those engaged in production, ought to be considered the responsibility of the entire society, Besides, poor relief solely tackled, to some extent, a matter of need, but, Want in the words of Sir William Beveridge, is only one of the five giants on the road of reconstruction and in some ways that the best to attack. The others are illness, Ignorance, uncleanness and Idleness. Hence, social insurance and social welfare schemes came into existence. (Kohli, Gupta, Banerjee, \& Ingle, 2017).

These contingencies also includes illness, disability, accidents, unemployment, old age and widowhood. Social security measures can take different meanings depending on the context in which they are implemented (Kohli, 2017). In developed countries economic insecurity is a phenomenon driven by continent poverty. Most of the rural and informal sector workers in the world do not have any social security measures. In most of the developing countries the rural and informal sector constitutes the bulk of the population. Social Security is that the security that society particularly state and employer furnish through applicable organisation against the risks that an individual of little means that cannot, today, rise by himself or maybe in private combination together with his fellow countrymen. Thus, Social Security measures have a twofold significance for each developing country. They represent a crucial step towards the goal of a state, by improving living and working conditions and affording the individuals protection against the uncertainties of the long run. (Siefert, 2015). They do not have any security or insurance nor do they have any representatives that might help them by fighting for these benefits. Hence the social security measures were implemented and brought into force by the Government to protect these kinds of workers. The State Governments administer this Act and are sceptered to increase the applying of this Act to alternative categories of persons or diseases not lined by the Act. The State Governments have appointed labour compensation commissioners for the settlement of controversial cases. Under this Act, the employer is vulnerable to pay, the compensation just in case of private injury caused out of the blue arising out of and within the course of employment. No compensation is, however, owed if the incapacity doesn't last for more than three days or if it's caused by the default of the employee, not leading to death. Besides, body injuries, compensation is 
additionally payable within the case of certain occupational diseases as given in schedule III. The amount of compensation payable depends upon the character of injury and therefore the average monthly wages of the employee involved. (Panda, 2014; Siefert, 2015).

There are two main approaches to social security Social assistance and social insurance. Social assistance is the method to provide benefits as of rights usually of small means in amounts sufficient to meet a minimum standard of living from general revenues of the state. It is a non contributory benefits towards the maintenance of vulnerable groups such as children, mothers, aged people, disabled etc. Very much essential for the effective working of the economic system. Measures adopted by totally different societies for safeguarding the impoverished people are manifold. beginning with individual act of charity and financial aid, these devices progressed to incorporate mutual benefit schemes, each formal and informal. Then followed state support and state participation, finally culminating within the present pattern wherever social insurance measures kind a significant plank of Governmental policy in several countries. In early stage, workers sought-after protection against the contingencies they were exposed to through tiny savings, employer liability or private insurance. Later, protecting legislation became common on the speculation that the employer who started a works created an atmosphere that was possible to cause injury to his work individuals and therefore the loss sustained by the victim ought to be a charge on the employer. (Bhatnagar, 1984). Whereas social insurance is a method to provide benefits as a matter of right for the person's of small earnings, in amounts which combine the contributions of the beneficiary with subsidies from the employer and the state. Characteristic feature of this is the beneficiaries, employers and the government make contributions towards the creation of common pool, out of which benefits are paid are paid to the members in the event of any contingency. But most of the unorganised workers suffer from the lack of awareness about social security and the social welfare benefits the government offer to the people.(Darooka, 2016).

Social security is a dynamic conception which is considered in all advanced countries of the world as an indispensable chapter of the national programme to strike at the root of poverty, unemployment and disease. Social security is a security that society furnishes through appropriate organisation against certain risks to which its members are exposed (Varandani, 1987). These risks are essentially contingencies against which the individual of small means or the worker cannot effectively provide. Social security is a very comprehensive term and 
includes in its, schemes of social insurance and social assistance as well as certain schemes of commercial insurance. In modern times social security is influencing both social and economic factors. Social security envisages that the members of a community shall be protected by a collective action against social risks causing undue hardship and privatization to the individuals whose private resources can seldom be adequate to meet them. Social security means the security of income to take the place of earnings when they are interrupted by unemployment, sickness or accident to provide through the old age to provide against loss of support by the death of another person and to meet exceptional expenditure connected to the birth death or marriage of a person. (Rao, 1957; Varandani, 1987). In 1923, the govt of India passed the Workmen's Compensation Act. This Act, marked the start of Social Security system in India. the object of this Act is to impose upon employers an obligation to pay compensation to employees for accidents arising out of and within the course of employment. It additionally helps to cut back the amount of accidents, to relinquish employees larger freedom from anxiety and to create business more enticing to employees. The Act has been amended many times. The last modification was made in 1962. The Act applies to any or all permanent workers used in railways, factories, mines, plantations, automatically propelled vehicles, construction work and bound alternative dangerous operations. It doesn't apply to members of defense force, casual employees and employees covered under the Employees State Insurance Act, 1948 (Naidu, 2003).

The concept of social security is based on the ideals of human dignity and social justice. The main idea behind social security measures is that a citizen who has contributed or is likely to contribute to his country's welfare and who should be given protection against certain hazards. Social security means a guarantee provided by the state through it's appropriate agencies against certain risks to which the members of the society may be exposed (Patro). Everyone has the right to a standard of living adequate for the health and well-being of himself and of his family, as well as food, clothing, housing and medical cases and necessary social services and also the right to security within the event of unemployment, sickness, disability, widowhood, old age, or other lack of livelihood, or circumstances on the far side his control After independence, India declared itself a state under the constitution and as such many Social Security measures were introduced. According to Article forty one of the constitution of India The state shall among limits of its economic capability and development create effective provision securing the correct to work, to education and to public help just in case of unemployment, old age, illness and disability and different cases of unserved wants. 
Social security is a vital step towards the goal of state. several State Governments have introduced maturity schemes and different varieties of social insurance benefits. many laws are enacted since independence in the country to produce for Social Security to the employees. (Bhattarai, 1989; Patro).

The role of International Labour Organisation in certain standards of social welfare has been vital. The Social Security Convention adopted in 1952 embodies universally accepted basic principles and common standards of Social Security. In order to supply illness benefits to workers, the employees State Insurance Act was passed in 1948. The Act applies to all nonseasonal factories run with power and employing ten or additional staff or twenty or a lot of staff, if run without power. It covers every kind of employees - manual, clerical, superior and technical-not drawing a wage of over Rs.1600 per month. The theme is required and causative. required within the sense that everyone employees covered underneath the Act should be insured and contributory within the sense that it's supported by the contributions from staff and employers. The administration of the theme has been entrusted to an autonomous body known as the workers State Insurance Corporation. The corporation is managed by an administration of forty persons representing the union and the State Governments, Parliament, employers and employees' organisation and the medical community. This body elects a commission consisting of thirteen members. a third body known as Medical benefit Council is established consisting of twenty six members to advise the corporation on matters concerning medical edges. State-wise regional boards have conjointly been implanted. (Agarwal, 1991).

In our country variety of Social Security legislations are enacted from time to time. The earliest of such legislation is that the Workmen's Compensation Act that ensures payment of compensation just in case of a personal injury caused by an accident arising out of and within the course of employment. Maternity benefit Acts have additionally been elapsed the Parliament and additionally in numerous States (van Ginneken, 2008). Although Social Security measures had been introduced in several countries decades past, in India they were introduced only when the independence of the country attributable to the shortage of official sympathy and also the weakness of trade unions. Thus, the importance of social insurance measures in India can not be exaggerated. Social security is a vital step towards the goal of state. several State Governments have introduced maturity schemes and different varieties of 
social insurance benefits. Many laws are enacted since independence in the country to produce Social Security to the employees. (Gourja, 1981).

It is a well-established fact that ours is a poor country and also the wages of our employees are therefore low so grudging on permit something however a below subsistence standard. In some elements of the country, it's too low to maintain a minimum standard (Agarwala, Kumar, \& Riboud, 2004). Sir William beveridge has justifiedly remarked that the lot of you are poor, the lot of you need social security. Really social insurance may be a measure to extend the national welfare (Moorthy, 1954). Indian employee consists of social evils like illness, unemployment, ignorance, uncleanness and illiteracy that endanger the security of their life. They realize themselves unable to fight against these contingencies thanks to their low earnings, high costs, high birth and death rates etc (Heredero, 2009). The worries for maintaining himself and his dependents ultimately have an effect on the potency of the employee to a good extent(Kohli et al., 2017). The provisions of social insurance measures might persuade be of nice facilitate to the employees in emergencies. several social evils like beggary, dishonesty, prostitution etc., occur solely in poorness and might be removed through to social insurance schemes (Gupta, 1993). The aim of this research is to analyse the effectiveness of social security measures in India implemented by the government. To know whether there are enough social security measures to protect labours in India. To analyse whether the Social security schemes in India covers treatment, rehabilitation and compensation.

\section{Hypothesis}

\section{Null hypothesis}

There is no significant association between the educational qualification and effectiveness of social security measures in India implemented by the government for the protection of workers.

\section{Alternate hypothesis}

There is a significant association between the educational qualification and effectiveness of social security measures in India implemented by the government for the protection of workers.

\section{MATERIALS AND METHODOLOGY :}


The study deals with empirical research i.e., non-doctrinal study. It deals with both primary as well as secondary sources of data and various secondary sources like books, articles, research papers etc. were used as reference. The study deals with survey method and the main tool for calculating or analysing the results in Pearson chi-square table and the cross tabulation count. The method of primary data collection is through direct survey method by people's opinions and answers to the questionnaires.Convenience sampling method was used for the purpose of this study. There are a total of 1444 samples collected with regard to this study. The independent variable used for this study is Educational qualification. The dependent variables used for this study are enactment of enough social security measures to protect labours in India and the enactment of social security schemes in India covers treatment, rehabilitation and compensation.

\section{Results and Analysis}

Table 1: Enactment of adequate Social Security measures in India

\begin{tabular}{|l|l|l|l|l|l|l|}
\hline $\begin{array}{l}\text { Educational } \\
\text { qualification }\end{array}$ & $\begin{array}{l}\text { Strongly } \\
\text { agree }\end{array}$ & Agree & Neutral & disagree & $\begin{array}{l}\text { strongly } \\
\text { disagree }\end{array}$ & Total \\
\hline Illiterate & 63 & 32 & 51 & 19 & 5 & 170 \\
HSC & 36 & 62 & 164 & 116 & 8 & 386 \\
UG & 110 & 150 & 39 & 192 & 15 & 506 \\
PG & 33 & 84 & 39 & 66 & 7 & 229 \\
Others & 12 & 57 & 10 & 70 & 4 & 153 \\
Total & 254 & 385 & 303 & 463 & 39 & 1444 \\
\hline
\end{tabular}

According to the above tabulation when the respondents are asked are there enough social security measures to protect labours in India 254 respondents have strongly agreed to the above statement 385 have agreed to the above statement 303 respondents have given neutral answer 463 respondents have disagreed to the above statement and 39 have strongly disagreed with the above statement which states that there are enactment of adequate social security measures in India for protection of labour.

Table 2:

Chi-Square Tests

\begin{tabular}{|l|l|l|} 
Value & df & Asymp. Sig. (2-sided)
\end{tabular} 


\begin{tabular}{|l|l|l|l|}
\hline Pearson Chi-Square & $2.938 \mathrm{E} 2^{a}$ & 16 & .000 \\
Likelihood Ratio & 296.970 & 16 & .000 \\
Linear-by-Linear Association & 7.489 & 1 & .006 \\
N of Valid Cases & 1444 & & \\
\hline
\end{tabular}

a. 2 cells $(8.0 \%)$ have expected count less than 5 . The minimum expected count is 4.13 .

According to the above chi square test the Pearson value falls below 0.005 that is the value obtained is 0.000 hence the null hypothesis is rejected and alternate hypothesis is accepted . Hence there is a significant association between the educational qualification and social security measures to protect labours in India.

Table 3: Social security schemes covering treatment, rehabilitation and compensation.

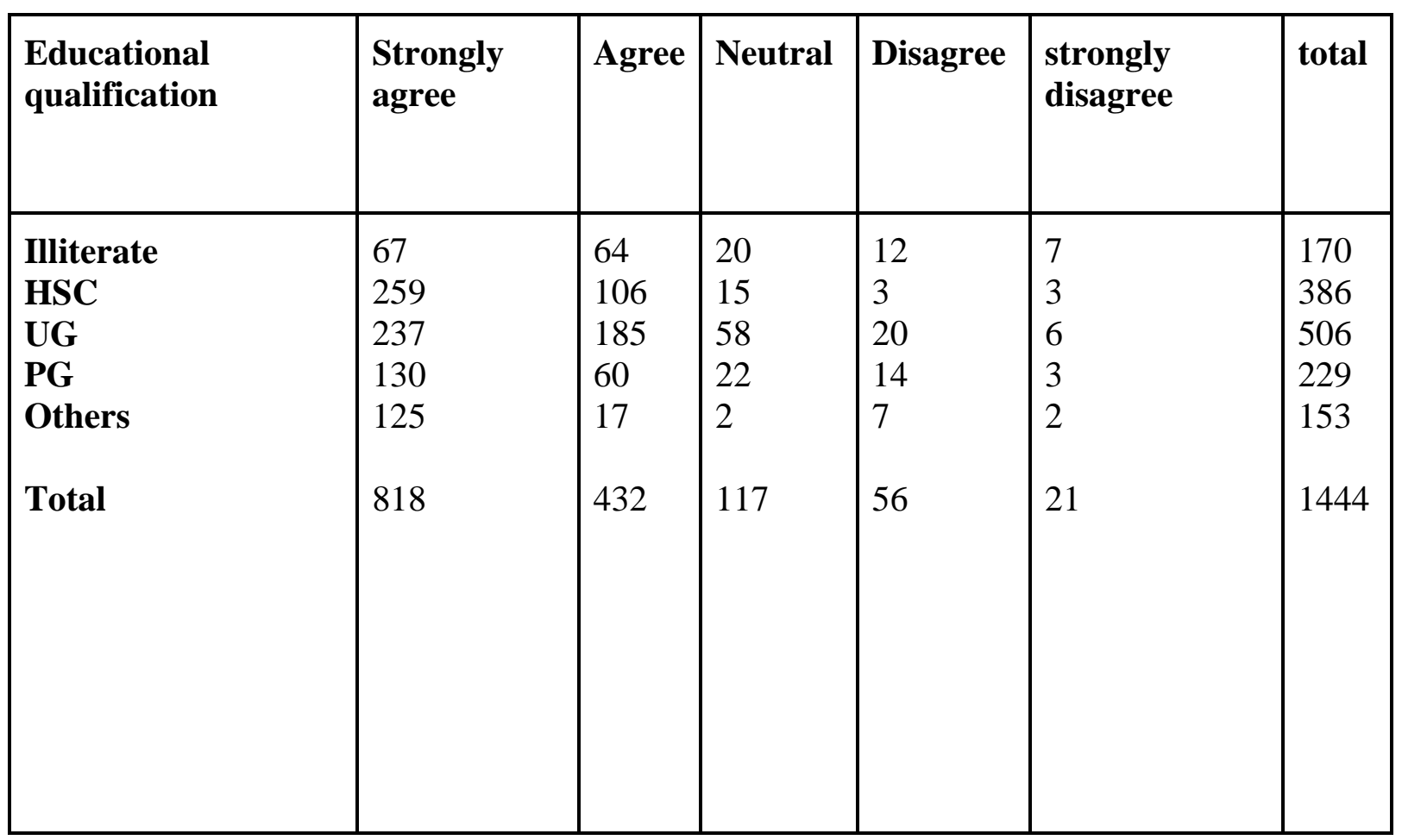

From the above cross tabulation when the respondents are asked whether the social security schemes in India covers treatment, rehabilitation and compensation majority of the respondents that is 818 respondents have strongly agreed to the above statement, 432 have agreed to the statement 117 have given neutral answer, 56 have disagreed and 21 have strongly disagreed to the above statement.

Table 4: 


\section{Chi-Square Tests}

\begin{tabular}{|l|l|l|l|}
\hline & Value & df & Asymp. Sig. (2-sided) \\
\hline Pearson Chi-Square & $1.274 \mathrm{E} 2^{\mathrm{a}}$ & 16 & .000 \\
Likelihood Ratio & 138.089 & 16 & .000 \\
Linear-by-Linear Association & 8.554 & 1 & .003 \\
N of Valid Cases & 1444 & & \\
\hline
\end{tabular}

a. 3 cells $(12.0 \%)$ have expected count less than 5 . The minimum expected count is 2.23 .

From the above chi square test the Pearson value falls below 0.05 that is the value is 0.000 hence the null hypothesis is rejected and alternate hypothesis is accepted. Hence there is a significant association between the educational qualification and social security schemes in India covering treatment, rehabilitation and compensation.

\section{Discussions}

The social security is the protection which society provides for it is members through a series of public measures against economic and social distress that otherwise would be caused by stoppage or substantial reduction of earnings from sickness ,maternity, employment, invalidity and death. The social security refers to a state of mind as well as objective facts. It is mainly directed towards providing income security to the workers as a preliminary to a state of social and psychological well being. The social security is broadly understood as the end product of possession of goods, position in life and supply of services to help a man to live in wholesome contentment and communication with others in the group. The social security refers to a set of institutional and personal services provided either by the state or voluntary organisations to prevent the incidence or to reform or rehabilitate the victims of disabilities, disorganisation or delinquency and so on.

According to the above tabulation when the respondents are asked are there enough social security measures to protect labours in India 254 respondents have strongly agreed to the above statement 385 have agreed to the above statement 303 respondents have given neutral answer 463 respondents have disagreed to the above statement and 39 have strongly disagreed with the above statement. According to the above chi square test the Pearson value falls below 0.005 that is the value obtained is 0.000 hence the null hypothesis is rejected and alternate hypothesis is accepted. Hence there is a significant association between the educational qualification and social security measures to protect labours in India. 
From the above cross tabulation when the respondents are asked whether the social security schemes in India covers treatment, rehabilitation and compensation majority of the respondents that is 818 respondents have strongly agreed to the above statement, 432 have agreed to the statement 117 have given neutral answer, 56 have disagreed and 21 have strongly disagreed with the above statement. From the above chi square test the Pearson value falls below 0.05 that is the value is 0.000 hence the null hypothesis is rejected and alternate hypothesis is accepted. Hence there is a significant association between the educational qualification and social security schemes in India covering treatment, rehabilitation and compensation.

\section{Conclusion}

These social security measures are vital for each industrialization plan, for not solely do they allow workers to become more economical, however they additionally reduce wastage arising from industrial disputes. The working days lost on account of illness and incapacity additionally represent an important drain on the slender resources of the employee and on the economic output of the country. These measures additionally scale back absence and labour turnover and facilitate within the formation of stable and economical labour force. Thus, lack of social security measure impedes production and prevents the formation of stable and economical labour force. Considering the Importance of Social Security, the International Social Security Association justifies the same that, No peace while not social justice and no justice while not Social Security. Hence from the above research it's concluded that there is a significant association between the educational qualification and effectiveness of social security measures in India implemented by the government for the protection of workers. Hence the alternate hypothesis is accepted and the null hypothesis is rejected. Hence there is a significant association between the independent variable and the dependent variable which concludes that the social security measures implemented in our country function effectively in protection of workers.

\section{References}

1. Agarwala, R., Kumar, N., \& Riboud, M. (2004). Reforms, Labour Markets, and Social Security in India. Oxford University Press, USA. 
2. Agarwal, B. (1991). Social Security and the Family: Coping with Seasonality and Calamity in Rural India. Social Security in Developing Countries, pp. 171-244. https://doi.org/10.1093/acprof:oso/9780198233008.003.0005

3. Bhatnagar, D. (1984). Labour welfare and social security legislation in India. Humanities Pr.

4. Bhattacharya, V. R. (1970). Some Aspects of Social Security Measures in India.

5. Bhattarai, A. K. (1989). Social security programmes in India. International Social Security Review, Vol. 42, pp. 479-488. https://doi.org/10.1111/j.1468246x.1989.tb00259.x

6. Darooka, P. (2016). Road to Rights: Women, Social Security and Protection in India. SAGE Publications India.

7. Gourja, M. (1981). The contribution of social security to development objectives: the role of income support measures. International Social Security Review, Vol. 34, pp. 131-150. https://doi.org/10.1111/j.1468-246x.1981.tb00692.x

8. Gupta, R. D. (1993). Social security and mutual assistance in India: A preliminary account. International Social Security Review, Vol. 46, pp. 53-68. https://doi.org/10.1111/j.1468-246x.1993.tb00383.x

9. Heredero, A. G. (2009). Social Security: Protection at the International Level and Developments in Europe. Council of Europe.

10. Kohli, C. (2017). Social Security Measures for Elderly Population in Delhi, India: Awareness, Utilization and Barriers. JOURNAL OF CLINICAL AND DIAGNOSTIC RESEARCH. https://doi.org/10.7860/jcdr/2017/21271.9814

11. Kohli, C., Gupta, K., Banerjee, B., \& Ingle, G. K. (2017). Social Security Measures for Elderly Population in Delhi, India: Awareness, Utilization and Barriers. Journal of Clinical and Diagnostic Research: JCDR, 11(5), LC10-LC14.

12. Moorthy, B. M. L. (1954). Social security in India: (embodying the schemes envisaged in the Employees' State Insurance Act, 1948, as amended in 1951 and Provident Funds Act, 1952 as amended in 1953).

13. Naidu, K. M. (2003). Social security of labour in India and economic reforms.

14. Panda, P. K. (2014). Human Development and Social Security in India.

15. Patro, D. R. S. (n.d.). SOCIAL SECURITY IN INDIA. Lulu.com.

16. Rao, D. N. (1957). Social security in India. 
17. Siefert, S. (2015). I. Introduction - Social Security Provision in India and China. Social Security in India and China, pp. 21-43. https://doi.org/10.5771/9783845270197-21 